(RESEARCH ARTICLE)

\title{
Toxicity effects of waste dry cell battery on the haematology and biochemistry of blood, gills and liver of Clarias gariepinus fingerlings
}

\author{
Audu Bala Sambo 1, ${ }^{*}$, Damshit Margaret 1, Wakawa Idi Audu 4, Ajima Malachy Nwigwe Okechukwu ${ }^{2}$ \\ Sulaiman Yusuf ${ }^{3}$ and Wade John Wokton ${ }^{1}$ \\ ${ }^{1}$ Department of Zoology, Faculty of Natural Sciences, University of Jos. Nigeria. \\ 2 Department of Fisheries and Aquaculture Technology, Federal University of Technology, Owerri, Nigeria. \\ ${ }^{3}$ Department of Zoology, Nassarawa State University, Keffi, Nassarawa State, Nigeria. \\ ${ }^{4}$ Department of Biology, Umar Suleiman College of Education, Gashua, Yobe State, Nigeria.
}

Publication history: Received on 27 April 2020; revised on 04 May 2020; accepted on 06 May 2020

Article DOI: https://doi.org/10.30574/wjarr.2020.6.2.0129

\begin{abstract}
Indiscriminate dumping of spent dry cell batteries have continuously polluted aquatic environments usually as surface run-offs with deleterious effects on aquatic fauna including Fish. Toxicity effects of water soluble fractions (WSFs) of waste dry cell battery (WDCB) on blood, gills and liver of Clarias gariepinus fingerlings were investigated under laboratory conditions. Acute (96 hr.) and sub lethal (56 days) bioassays were separately conducted on $120 \mathrm{no}$. $C$. gariepinus fingerlings stocked ten (10) per tank in twelve (12) circular tanks, each in randomized block design. Fish were exposed to acute $(0.31,0.63,1.25,2.50$ and $5.00 \mathrm{~g} / \mathrm{L})$ and sub lethal $(0.02,0.04,0.07,0.14$, and $0.28 \mathrm{~g} / \mathrm{L})$ concentrations with a control $(0.00 \mathrm{~g} / \mathrm{L})$ in replicates. The $96 \mathrm{hr}$. LC 50 of WDCB on C. gariepinus fingerlings was $0.84 \mathrm{~g} / \mathrm{L}$ with upper $(1.12 \mathrm{~g} / \mathrm{L})$ and lower $(0.49 \mathrm{~g} / \mathrm{L})$ confidence limits and cumulated to behavioural changes and death of the fish. Significant alterations $(\mathrm{P}<0.05)$ in haematological [white blood cells $(\mathrm{WBC})$ packed cell volume $(\mathrm{PCV})$, red blood cells (RBC) and haemoglobin (Hb)] and biochemical [Alkaline phosphatase (ALP), Aspartate aminotransferase (AST) and Alanine aminotransferase (ALT)] parameters of the gills and liver were observed in both toxicity tests. However, no mortality was recorded in sub lethal bioassay. Waste dry cell battery is hazardous to $C$. gariepinus fingerlings. Therefore indiscriminate disposal of spent dry cell battery should be discouraged in order to safeguard riparian ecosystem and aquatic fauna.
\end{abstract}

Keywords: Spent non- rechargeable dry cell battery; Blood cells; Enzymes; Organs; African catfish

\section{Introduction}

Aquatic pollution emanates from a variety of sources mainly anthropogenic and natural sources. Of the numerous ecosystem pollutants, heavy metals of anthropogenic sources immensely contribute to accumulation of toxic metals in the aquatic environment [1] and quite a number of these are from rechargeable and non-rechargeable dry cell or Zinccarbon batteries. Kalay and Canli [2] reported that heavy metals are natural trace components of the aquatic system, but their levels have increased due to domestic, industrial mining and agricultural activities. In developing countries like Nigeria, consumption of Zinc-carbon (Zn-C) dry cell battery is on the increase mainly due to their highly efficient portable electrical properties and low cost ratio. Zn-C batteries are generally used in radios, recorders, remote controls, calculators, toys and many other objects where small quantities of power are required. However, due to their short lifespan, Zn-C dry cells run out rapidly and are thrown away [3] indiscriminately and invariably end in aquatic habitats where they release very large quantities of heavy metals such as Zinc and Manganese.

Allochthonous and autochthonous inputs of pollutants impact immensely on aquatic fauna especially fish. This makes them ideal sentinels for aquatic pollution studies mainly due to their dependent aquatic mode of life, wide distribution

* Corresponding author: Audu Bala Sambo

Copyright (C) 2020 Author(s) retain the copyright of this article. This article is published under the terms of the Creative Commons Attribution Liscense 4.0. 
and high mobility in all the reaches of the aquatic habitat. These aquatic fauna are highly susceptible to the slightest forms of change in water quality. Therefore, fishes, in comparison with invertebrates, are more sensitive to many toxicants and are convenient test candidates for indication of ecosystem health $[4,5]$. Fishes are considered as excellent bio monitors of the aquatic system for the estimation of metal pollution levels $[6,7]$ in several ways. First, they serve as indices of delineating specific natural characteristics of the aquatic ecosystem and in assessing changes to aquatic medium [8]. Second, they easily absorb toxicants from their environment, bio accumulate, bio concentrate and bio magnify them as the level of intake exceeds the levels of their conversion, transformation and excretion thereby leading to a threshold. Third, because fishes are at the end of the food chain, they may accumulate metals and pass them to human beings through food causing chronic or acute diseases [9].

It has been reported $[10,11]$ that the uptake of heavy metals by fishes usually stems from a variety of sources mainly by ingestion of contaminated foods through the gastrointestinal tract or by diffusion through the gills and skin. Heavy metals at high concentrations can cause harmful effects on the haematology of fishes which invariably cause long term ecotoxicological effects on the organisms that eat them [10]. The heavy metals become lodged in various organs or tissues $[12,13]$ especially the liver and are excreted through the blood as the ideal vehicle of transportation which can invariably demonstrate the extent of pollution of the aquatic habitat caused by heavy metals discharged from WDCB. This serve as baseline information of the deleterious effects of WDCB on aquatic animals and how it's toxicity affects the ecological balance of populations in the aquatic environment [14].

Haematological parameters have been recognized as valuable tools for monitoring fish health [15]. According to Karruppasamy et al. [14] exposures of Channa punctatus to low doses of cadmium (Cd) reduced total erythrocyte count (RBC), haemoglobin ( $\mathrm{Hb}$ ) content, packed cell volume (PCV), mean corpuscular volume (MCV) and mean corpuscular haemoglobin (MCH), due to haemolysis. Dhanapaktam and Ramasamy [15] reported that increase in mean corpuscular haemoglobin concentration (MCHC) and MCV of carp were dependent upon exposure period to Copper (Cu) and Zinc (Zn). Also, Thangam, et al. [16] reported decrease in RBC after exposing Cyprinus carpio to copper. The obvious sign of highly polluted water is the presence of dead fish, which is readily apparent in acute toxicity test but sub lethal toxicity might only result in the impairment of the proper functioning of fish organs signifying unhealthy fish.

Biochemical parameters such as Aspartate aminotransferase (AST), Alanine aminotransferase (ALT), Alkaline phosphatase (ALP), total protein (TP), and direct bilirubin (DB) [17] are often used in assessing the integrity of liver cells of fishes. Increase in aminotransferases in blood is an indication of cellular damage thus alterations in ALT, AST, ALP and Lactate dehydrogenase (LDH) of fish exposed to toxicant indicate degeneration and dysfunction of liver [18]. Firat, et al [18] reported increase in serum ALT and AST activities in Oreochromis niloticus in response to copper, lead and cypermethrin exposure.

Environmental stressors such as heavy metals may change the biochemical parameters of fish [19]. Measurement of plasma enzymes can therefore be useful in diagnosing the general health status of fish affected by toxicants [20]. The aim of this study is to assess the toxicity effects of WSFs of WDCB on haematology and blood biochemistry of $C$. gariepinus fingerlings.

\subsection{Purpose}

Water soluble fractions (WSFs) of WDCB contain toxic heavy metals which are washed into aquatic environment by rains which result to lethal effects on aquatic fauna. This study is aimed at investigating the haematological and biochemical alterations caused by acute and sub lethal concentrations of WSFs of WDCB on the blood, gills and liver of C. gariepinus fingerlings.

\section{Material and methods}

\subsection{Collection and Preparation of WDCB}

Non-rechargeable plastic coated waste dry cell batteries (Tiger Head brand®) were collected from a riparian dump site along River Dilimi Jos, Plateau State, Nigeria and transported to the Applied Hydrobiology and Fisheries research laboratory of the Department of Zoology, University of Jos, Jos, Nigeria .The plastic wrappings were carefully removed and the WDCB allowed to decompose further for two (2) weeks on surgical tray until the Zinc anode casing turned whitish indicating the formation of Zinc -Ammonium chloride complex. The decomposed components were collected and weighed using meltler H30 and crushed using ceramic pestle and mortar into fine powder ( $90 \mu \mathrm{m}$ mesh sieve) of fifty (50 g) grams weight with a ceramic pestle and mortar. 


\subsection{Preparation of WSFs of WDCB and acute toxicity test}

A range finding test (RFT) of the WDCB was conducted on $C$. gariepinus fingerlings (mean weight $9.77 \pm 0.42 \mathrm{~g}$ ) in a static bioassay to obtain a realistic concentration that would kill $50 \%$ of test fish after 96 hours exposure. Five (5) definitive test concentrations were prepared by weighing $0.31,0.63,1.25,2.50$ and $5.00 \mathrm{~g} / \mathrm{L}$ of the WDCB powder and macerating each of the graded concentrations into five clean plastic circular tanks containing one (1) liter of distilled water for 24 hrs. The mixtures were separately filtered through a funnel choked with nonabsorbent cotton wool and the filtrates were stored in clean labeled conical flasks for subsequent use.

\subsection{Acute toxicity test}

A total of 120 mixed sex cohorts of $C$. gariepinus fingerlings were obtained and distributed into five (5) tests and one (1) control circular plastic tanks of $(20 \mathrm{~L})$ capacity each containing ten (10) mixed sex of $C$. gariepinus fingerlings in randomized block design. Fish were acclimatized for 24 hours during which feeding was stopped and were exposed to the graded concentrations of WSFs of WDCB following the methods described by [21] for the conduct of acute toxicity test with fish. The LC50 was determined using graphical methods (Probit Method).

\subsection{Sub lethal toxicity test}

Sub lethal concentrations of WDCB were calculated as $1 / 3^{\text {rd }}$ of $96 \mathrm{hr}$. LC50 $(0.28 \mathrm{~g} / \mathrm{L}), 1 / 6^{\text {th }}$ of $96 \mathrm{hr}$. LC50 (0.14 g/L), $1 / 12^{\text {th }}$ of $96 \mathrm{hr}$. LC $50(0.07 \mathrm{~g} / \mathrm{L}), 1 / 24^{\text {th }}$ of $96 \mathrm{hr}$. LC $50(0.04 \mathrm{~g} / \mathrm{L})$ and $1 / 48^{\text {th }}$ of $96 \mathrm{hr}$. LC $50(0.02 \mathrm{~g} / \mathrm{L})$ based on $96 \mathrm{hr}$. LC 50 of the WSFs of WDCB to C. gariepinus fingerlings which was calculated as $0.84 \mathrm{~g} / \mathrm{L}$. The sub lethal test concentrations consist a total of 120 no. of $C$. gariepinus fingerlings with ten (10) fingerlings per test tanks and a control (dechlorinated municipal water) in replicates. A renewable static bioassay was used in order to maintain the concentration of the WSFs of WDCB and was renewed fortnightly. During sub lethal tests, fish were fed to satiation and left over feed and fecal matter were siphoned while lost solution was replaced by equivalent concentration of toxicant. Photoperiod was normal, 12 light: 12 dark diurnal cycle throughout the 8 weeks bioassay. The fish were assessed for changes in blood and biochemical indices at the termination of the 56 days sub lethal test,

\subsection{Water quality parameters of experimental tanks}

During the acute and sub lethal bioassay tests, standard methods of [22] were used to determine water quality parameters of the fish tanks exposed to toxic concentrations of WSFs of WDCB including those of the control tanks, namely, Temperature $\left({ }^{\circ} \mathrm{C}\right), \mathrm{pH}$, Free Carbon (iv) oxide $\left(\mathrm{CO}_{2}\right)$, Total Alkalinity (TA), Dissolved Oxygen (DO), Nitrite, and un ionized Ammonia $\left(\mathrm{NH}_{3}\right.$ ). Samples were taken before and final stages (4days-acute) and fortnightly (56 days-sub lethal) except temperature that was measured every 24 hours throughout the experimental periods.

\subsection{Haematological Analysis}

Two fish from each of the experimental media were collected and blood drawn from the caudal peduncle of the fish into heparinized micro-haemacrit tubes. White blood cell (WBC) and Erythrocyte (RBC) counts were determined using standard haemotocytometer as described by [23]. Packed Cell Volume was determined using micro haematocrit centrifuge model (RM12C). The Haematocrit was analyzed after blood centrifugation for five mins at $14000 \mathrm{x} g$ in heparinized glass capillaries using a micro haematocrit centrifuge (Hawkesley and Sons, Lancing, UK) at $25^{\circ} \mathrm{C}$ [24]. The haematocrit reader was used to read the PCV values and the result was expressed as percentage of the blood sample. Haemoglobin $(\mathrm{Hb})$ was determined using standard method as described by [24]. Data obtained in the experiments were subjected to analysis of variance (ANOVA) single classification.

\subsection{Biochemical analysis}

Only one C. gariepinus fingerlings from each of the test tanks of the two experiments (acute and sub lethal) was removed, sacrificed and dissected and the liver and gills excised. The organs were rinsed in distilled water to remove trace of blood [25]. The liver and gill samples were macerated in normal saline and gently crushed using a ceramic mortar and pestle [25]. The samples were centrifuged for 5 minutes at $1000 \mathrm{rpm}$ to obtain supernatants which were used for analyses according to the methods of [26].

Physiological enzymes such as alkaline phosphatase, aspartate aminotransferase and alanine aminotransferase were determined using the enzyme tests kits, AGAPPE for quantitative in vitro determination following the standard procedures of Reitman and Frankel (1957) [27]. 


\section{Results}

\subsection{Water quality parameters of experimental tanks during acute and sub lethal toxicity tests of WSFs of WDCB on C. gariepinus fingerlings}

The water quality parameters of experimental tanks during the 96hr. and sub lethal toxicities are presented in Tables 1 and 2 respectively. Recorded water quality parameters during the 96hr. toxicity showed irregular patterns with increase in the concentrations of the test substance except free $\mathrm{CO}_{2}$, which increased as concentration of WSFs of WDCB increased. Mean free $\mathrm{CO}_{2}$ was lowest $(1.90 \pm 0.14 \mathrm{mg} / \mathrm{L})$ in the control and progressively increased to $9.55 \pm 0.21 \mathrm{mg} / \mathrm{L}$ in the highest concentration of the toxicant. Mean pH was highest $(8.30 \pm 0.00)$ in control $(0.00 \mathrm{~g} / \mathrm{L})$ and lowest $(7.90$ $\pm 0.00 \mathrm{~g} / \mathrm{L})$ in the highest concentration $(5.00 \mathrm{~g} / \mathrm{L})$ of the toxicant. Mean total alkalinity (TA) was highest $(95.00 \pm 1.40$ $\mathrm{mg} / \mathrm{L})$ in the control $(0.00 \mathrm{~g} / \mathrm{L})$ tank and lowest $(64.00 \pm 0.00 \mathrm{mg} / \mathrm{L})$ in concentration $0.63 \mathrm{~g} / \mathrm{L}$. Similarly, the highest mean DO content of $3.42 \pm 0.21 \mathrm{mg} / \mathrm{L}$ was recorded in the control tank and lowest $(2.07 \pm 0.23 \mathrm{mg} / \mathrm{L})$ in the highest (5.00 $\mathrm{g} / \mathrm{L})$ concentration of the WSFs of WDCB. Mean temperature ranged between 26.10 and $26.65{ }^{\circ} \mathrm{C}$ while, Ammonia $\left(\mathrm{NH}_{3}\right)$ was lowest $(0.29 \pm 0.01 \mathrm{mg} / \mathrm{L})$ in test tank exposed to $1.25 \mathrm{~g} / \mathrm{L}$ concentration of the toxicant and highest $(0.60 \pm 0.00$ $\mathrm{mg} / \mathrm{L})$ in the control. The lowest $(0.31 \mathrm{~g} / \mathrm{L})$ concentration of WSFs of WDCB recorded the highest nitrite value (0.06 $\pm 0.01 \mathrm{mg} / \mathrm{L})$ while the lowest nitrate value $(0.02 \pm 0.00 \mathrm{mg} / \mathrm{L})$ was recorded in the control. No significant difference ( $p>0.05)$ exist between recorded water quality parameters compared with control group.

Water quality parameters during the sub lethal toxicity also showed irregular pattern as concentration of WSFs of WDCB increases except free $\mathrm{CO}_{2}$ which invariably increased with increase in the concentration of the toxicant. $\mathrm{Mean}_{\text {free }} \mathrm{CO}_{2}$ was lowest $(1.66 \pm 0.24 \mathrm{mg} / \mathrm{L})$ in the control tank and progressively increased to $3.26 \pm 0.14 \mathrm{mg} / \mathrm{L})$ in the highest concentration $(0.28 \mathrm{~g} / \mathrm{L})$ of WSFs of WDCB. Mean $\mathrm{pH}$ ranged from 5.86 in the lowest WDCB concentration $(0.02 \mathrm{~g} / \mathrm{L})$ to $6.31 \pm 0.07$ in the control tank. Mean Total alkalinity values ranged from $31.10 \pm 0.19 \mathrm{mg} / \mathrm{L}$ in the control tank to 34.00 $\pm 0.37 \mathrm{mg} / \mathrm{L}$ in the highest $(5.00 \mathrm{~g} / \mathrm{L})$ concentration of the WSFs of WDCB. Mean DO was lowest $(2.98 \pm 0.48 \mathrm{mg} / \mathrm{L}) \mathrm{in}$ $0.07 \mathrm{~g} / \mathrm{L}$ and highest $(3.67 \pm 0.54 \mathrm{mg} / \mathrm{L})$ in $0.14 \mathrm{~g} / \mathrm{L}$ concentration of the toxicant. Temperature ranged from $17.22{ }^{\circ} \mathrm{C}$ in the highest toxicant concentration $(0.28 \mathrm{~g} / \mathrm{L})$ to $17.80{ }^{\circ} \mathrm{C}$ in test concentration of $0.04 \mathrm{~g} / \mathrm{L}$. The lowest value of $\mathrm{NH}_{3}(0.65$ $\pm 0.17 \mathrm{mg} / \mathrm{L})$ was recorded in the highest toxicant concentration $(0.28 \mathrm{~g} / \mathrm{L})$ and the highest value $(1.00 \pm 0.00 \mathrm{mg} / \mathrm{L}) \mathrm{was}$ recorded in recorded in the control tank. Nitrite was lowest $(0.03 \pm 0.01 \mathrm{mg} / \mathrm{L})$ in toxicant concentration of $0.14 \mathrm{~g} / \mathrm{L}$ and had the highest value of $0.05 \pm 0.01 \mathrm{mg} / \mathrm{L}$ in the control experiment. The water quality parameters during sub lethal bioassay showed that $\mathrm{pH}$, Free $\mathrm{CO}_{2}$ and Total Alkalinity were significantly different $(\mathrm{P}<0.05)$ in all the experimental tanks while DO, Temperature, Ammonia and Nitrite showed no significant difference $(\mathrm{P}>0.05)$ compared with the control.

\subsection{Effects of acute concentrations of WSFs of WDCB on mortality rate of $C$. gariepinus fingerlings}

The 96 hr. LC 50 toxicity effects of WSFs of WDCB on the mortality of $C$. gariepinus are presented in Table 3 . The percentage toxicity of WSFs of WDCB was observed to decrease with decrease in the concentration of the WSFs of WDCB. The toxic effects of WSFs of WDCB on C. gariepinus fingerlings resulted to $100 \%$ mortality in the highest concentration $(5.00 \mathrm{~g} / \mathrm{L})$, Concentrations $2.50,1.25$ and $0.63 \mathrm{~g} / \mathrm{L}$ recorded 90,70 and $40 \%$ mortalities respectively while the WSFs of WDCB at concentration of $0.31 \mathrm{~g} / \mathrm{L}$, recorded $20 \%$ mortality. In contrast, the control tank (0.00 g/L) did not record any mortality.

Table 1 Mean water quality parameters of experimental tanks with $C$. gariepinus fingerlings exposed to acute concentrations of WSFs of WDCB.

\begin{tabular}{lllllll}
\hline Parameters & \multicolumn{5}{c}{ Concentration (g/L) } \\
\cline { 2 - 7 } & 0.00 & 0.31 & 0.63 & 1.25 & 2.50 & 5.00 \\
\hline $\mathrm{pH}$ & $8.30 \pm 0.00$ & $8.05 \pm 0.01$ & $8.25 \pm 0.01$ & $8.15 \pm 0.01$ & $8.10 \pm 0.00$ & $7.90 \pm 0.00$ \\
Free $\mathrm{CO}_{2}(\mathrm{mg} / \mathrm{L})$ & $1.90 \pm 0.14$ & $2.50 \pm 0.00$ & $3.40 \pm 0.00$ & $5.15 \pm 0.49$ & $6.85 \pm 0.21$ & $9.55 \pm 0.21$ \\
$\mathrm{TA}(\mathrm{mg} / \mathrm{L})$ & $95.00 \pm 1.40$ & $72.00 \pm 4.24$ & $64.00 \pm 0.00$ & $77.00 \pm 1.41$ & $94.00 \pm 8.48$ & $75.00 \pm 0.00$ \\
DO $(\mathrm{mg} / \mathrm{L})$ & $3.42 \pm 0.21$ & $3.07 \pm 0.27$ & $2.89 \pm 0.27$ & $3.07 \pm 0.53$ & $2.87 \pm 0.42$ & $2.07 \pm 0.23$ \\
Temperature $\left({ }^{\circ} \mathrm{C}\right)$ & $26.10 \pm 0.14$ & $26.00 \pm 0.14$ & $26.30 \pm 0.00$ & $26.30 \pm 0.00$ & $26.75 \pm 0.07$ & $26.65 \pm 0.35$ \\
Ammonia $(\mathrm{mg} / \mathrm{L})$ & $0.60 \pm 0.00$ & $0.51 \pm 0.01$ & $0.41 \pm 0.01$ & $0.29 \pm 0.01$ & $0.45 \pm 0.01$ & $0.46 \pm 0.01$ \\
\hline
\end{tabular}




\begin{tabular}{ccccccc}
\hline Nitrite $(\mathrm{mg} / \mathrm{L})$ & $0.02 \pm 0.00$ & $0.06 \pm 0.01$ & $0.04 \pm 0.00$ & $0.04 \pm 0.01$ & $0.03 \pm 0.00$ & $0.05 \pm 0.01$ \\
\hline \multicolumn{6}{c}{$\pm=$ Standard error }
\end{tabular}

Table 2 Mean water quality parameters of experimental tanks with C. gariepinus fingerlings exposed to sub lethal concentrations of WSFs of WDCB for 56 days (8weks).

\begin{tabular}{lllllll}
\hline Parameters & \multicolumn{5}{c}{ Concentration (g/L) } \\
\cline { 2 - 7 } & 0.00 & 0.02 & 0.04 & 0.07 & 0.14 & 0.28 \\
\hline $\mathrm{pH}$ & $6.31 \pm 0.074$ & $5.86 \pm 0.196^{*}$ & $5.97 \pm 0.189^{*}$ & $6.07 \pm 0.082^{*}$ & $6.04 \pm 0.171^{*}$ & $6.23 \pm 0.142^{*}$ \\
Free CO $2(\mathrm{mg} / \mathrm{L})$ & $1.66 \pm 0.241$ & $1.77 \pm 0.134^{*}$ & $1.83 \pm 0.106^{*}$ & $2.20 \pm 0.141^{*}$ & $2.31 \pm 0.120^{*}$ & $3.26 \pm 0.135^{*}$ \\
$\mathrm{TA}(\mathrm{mg} / \mathrm{L})$ & $31.1 \pm 0.185$ & $31.3 \pm 0.457^{*}$ & $33.9 \pm 0.915^{*}$ & $34.0 \pm 0.763^{*}$ & $33.2 \pm 0.480^{*}$ & $34.0 \pm 0.371^{*}$ \\
DO (mg/L) & $3.31 \pm 0.438$ & $3.19 \pm 0.407$ & $3.35 \pm 0.255$ & $2.98 \pm 0.487$ & $3.67 \pm 0.544$ & $3.45 \pm 0.22$ \\
Temperature ( $\left.{ }^{\circ} \mathrm{C}\right)$ & $17.40 \pm 1.174$ & $17.30 \pm 1.140$ & $17.80 \pm 1.03$ & $17.40 \pm 1.075$ & $17.34 \pm 1.208$ & $17.22 \pm 1.11$ \\
Ammonia (mg/L) & $1.00 \pm 0.000$ & $0.82 \pm 0.07$ & $0.79 \pm 0.099$ & $0.76 \pm 0.107$ & $0.71 \pm 0.142$ & $0.65 \pm 0.165$ \\
Nitrite $(\mathrm{mg} / \mathrm{L})$ & $0.05 \pm 0.005$ & $0.043 \pm 0.008$ & $0.04 \pm 0.005$ & $0.04 \pm 0.009$ & $0.032 \pm 0.008$ & $0.04 \pm 0.008$ \\
\hline
\end{tabular}

Table 3 Mean mortality rates of $C$. gariepinus fingerlings exposed to acute (96 hrs LC 50 ) concentrations of WSFs of WDCB.

\begin{tabular}{lllllllll}
\hline \multirow{2}{*}{$\begin{array}{l}\text { Conc. } \\
\text { (g/L) }\end{array}$} & Log & Conc. & No. of & \multicolumn{4}{c}{ No of Mortality (Hours) } & \multicolumn{2}{l}{$\begin{array}{l}\text { Mortality } \\
\text { Fish }\end{array}$} & & & $\mathbf{1 2}$ & $\mathbf{2 4}$ & $\mathbf{7 2}$ & $\mathbf{9 6}$ & & $\begin{array}{l}\text { Probit } \\
\text { Mortality } \\
\text { (\%) }\end{array}$ \\
\hline 5.00 & 0.6989 & 10 & 4.0 & 5.0 & 1.0 & 0.0 & 100 & 8.7100 \\
2.50 & 0.3979 & 10 & 3.0 & 4.0 & 2.0 & 0.0 & 90 & 6.2518 \\
1.25 & 0.0969 & 10 & 1.0 & 1.0 & 2.0 & 3.0 & 70 & 5.5244 \\
0.63 & -0.2041 & 10 & 0.0 & 0.0 & 1.0 & 3.0 & 40 & 4.7487 \\
0.31 & -0.5088 & 10 & 0.0 & 0.0 & 1.0 & 1.0 & 20 & 4.1534 \\
0.00 & 0.0000 & 10 & 0.0 & 0.0 & 0.0 & 0.0 & 00 & 0.0000 \\
\hline
\end{tabular}

\subsection{Effect of acute concentrations of WSFs of WDCB on haematology of C. gariepinus fingerlings}

The results of analyses of haematology of $C$. gariepinus fingerlings exposed to graded acute concentrations of WSFs of WDCB showed significant difference $(\mathrm{P}<0.05)$ in the mean values of blood indices compared with the control group. PCV increased with increase in concentration of the test material. The highest toxicant concentration $(5.00 \mathrm{~g} / \mathrm{L})$ recorded the highest PCV $(28.20 \%)$, RBC $\left(3.20 \times 10^{9} \mathrm{mg} / \mathrm{L}\right)$, and $\mathrm{Hb}(9.41 \mathrm{~g} / \mathrm{L})$ however, had the lowest WBC $\left(9,448 \times 10^{9} \mathrm{mg} / \mathrm{L}\right)$ counts. The control $(0.00 \mathrm{~g} / \mathrm{L})$ tank recorded the lowest values of PCV $(15.50 \%), \mathrm{Hb}(5.18 \mathrm{~g} / \mathrm{L})$ and RBC $\left(1.10 \times 10^{9} \mathrm{mg} / \mathrm{L}\right)$ (Table 4).

Table 4 Blood indices of $C$. gariepinus fingerlings exposed to acute concentrations of WSFs of WDCB for $96 \mathrm{hr}$.

\begin{tabular}{lllllll}
\hline $\begin{array}{l}\text { Haematological } \\
\text { parameters }\end{array}$ & \multicolumn{5}{c}{ Toxicant Concentrations (g/L) } \\
\cline { 2 - 7 } & 0.00 & 0.31 & 0.63 & 1.25 & 2.50 & 5.00 \\
\hline PCV (\%) & $15.50 \pm 0.01$ & $16.80 \pm 0.02$ & $18.50 \pm 0.10$ & $21.00 \pm 0.00$ & $25.00 \pm 0.01$ & $28.20 \pm 0.02$ \\
$\mathrm{Hb}(\mathrm{mg} / \mathrm{L})$ & $5.18 \pm 0.02$ & $5.61 \pm 1.00$ & $6.17 \pm 0.04$ & $6.90 \pm 0.11$ & $8.20 \pm 0.12$ & $9.41 \pm 0.00$ \\
$\mathrm{RBC}\left(\mathrm{x} 10^{9} \mathrm{mg} / \mathrm{L}\right)$ & $1.10 \pm 0.00$ & $1.30 \pm 0.00$ & $1.40 \pm 0.01$ & $1.80 \pm 0.20$ & $2.40 \pm 0.20$ & $3.20 \pm .01$ \\
$\mathrm{WBC}\left(\mathrm{x} 10^{9} \mathrm{mg} / \mathrm{L}\right)$ & $25600 \pm 0.10$ & $20000 \pm 0.12$ & $18000 \pm 0.02$ & $15005 \pm 0.02$ & $10150 \pm 0.20$ & $9448 \pm .020$ \\
\hline
\end{tabular}




\subsection{Effects of sub lethal concentrations of WSFs of WDCB on haematology of $C$. gariepinus fingerlings}

The mean values of haematological analyses of $C$. gariepinus fingerlings exposed to sub lethal concentrations of WSFs of WDCB for 56 days are presented in Table 5. Statistical analysis revealed significant difference $(\mathrm{P}<0.05)$ between the various treatments. Mean WBC decreased as toxicant concentration increases. The highest toxicant concentration $(0.28$ $\mathrm{g} / \mathrm{L})$ recorded the lowest mean WBC $\left(1.70 \times 10^{9} \mathrm{mg} / \mathrm{L} \pm 0.00\right)$ while, the control tank recorded the highest value $(2.50 \mathrm{x}$ $\left.10^{9} \mathrm{mg} / \mathrm{L} \pm 0.00\right)$. Mean RBC count was lowest $\left(1.30 \times 10^{9} \mathrm{mg} / \mathrm{L} \pm 0.00\right)$ in the control and highest $\left(3.20 \times 10^{9} \mathrm{mg} / \mathrm{L} \pm 0.00\right)$ in the highest $(5.00 \mathrm{~g} / \mathrm{L})$ concentration of the WSFs of WDCB. Mean PCV also increased with increase in WSFs of WDCB concentration with the highest concentration $(0.28 \mathrm{~g} / \mathrm{L})$ recording the highest mean PCV $(27.00 \% \pm 0.28)$ and the control recorded the lowest $(14.50 \% \pm 0.00)$. Increase in WSFs of WDCB concentration showed increase in mean Hb. The highest concentration $(0.28 \mathrm{~g} / \mathrm{L})$ recorded mean $\mathrm{Hb}$ of $9.00 \pm 0.00 \mathrm{mg} / \mathrm{L}$ while the lowest $(0.02 \mathrm{~g} / \mathrm{L})$ toxicant concentration recorded mean $\mathrm{Hb}$ value of $3.00 \mathrm{mg} / \mathrm{L}$.

Table 5 Blood indices of $C$. gariepinus fingerlings exposed to sub lethal concentrations of WSFS of WDCB for 8 weeks

\begin{tabular}{lllllll}
\hline $\begin{array}{l}\text { Haematological } \\
\text { parameters }\end{array}$ & \multicolumn{5}{c}{ Toxicant Concentrations (g/L) } \\
\cline { 2 - 7 } & 0.00 & 0.02 & 0.04 & 0.07 & 0.14 & 0.28 \\
\hline $\mathrm{PCV}(\%)$ & $14.50 \pm 0.00$ & $15.00 \pm 0.00$ & $18.50 \pm 0.00$ & $17.00 \pm 0.00$ & $26.25 \pm 0.35$ & $27.00 \pm 0.28$ \\
$\mathrm{Hb}(\mathrm{mg} / \mathrm{L})$ & $4.83 \pm 0.00$ & $3.00 \pm 0.00$ & $6.17 \pm 0.00$ & $5.67 \pm 0.00$ & $8.75 \pm 0.00$ & $9.00 \pm 0.00$ \\
$\mathrm{RBC}\left(\mathrm{x} 10^{9} \mathrm{mg} / \mathrm{L}\right)$ & $1.30 \pm 0.00$ & $1.35 \pm 0.01$ & $1.80 \pm 0.00$ & $2.41 \pm 0.00$ & $2.30 \pm 0.12$ & $3.20 \pm 0.00$ \\
$\mathrm{WBC}\left(\mathrm{x} 10^{9} \mathrm{mg} / \mathrm{L}\right)$ & $2.50 \pm 0.00$ & $2.33 \pm 0.10$ & $2.10 \pm 0.00$ & $2.00 \pm 0.10$ & $1.77 \pm 0.00$ & $1.70 \pm 0.00$ \\
\hline \multicolumn{7}{c}{ \pm Standard Error }
\end{tabular}

\subsection{Biochemistry of gills and liver of $C$. gariepinus fingerlings exposed to acute concentrations of WSFs of WDCB}

The mean values of the ALP, AST and ALT of gills and liver of $C$. gariepinus fingerlings exposed to WSFs of WDCB are presented in Figures 1 and 2. The highest ALP activity $(6259.00 \mu / L)$ of gills was recorded in the highest acute concentration $(5.00 \mathrm{~g} / \mathrm{L})$ of WSFs of WDCB while the lowest $(2394.2 \mu / \mathrm{L})$ was recorded in $0.63 \mathrm{~g} / \mathrm{L}$ of the treatment concentration. Statistical analyses showed significant difference $(\mathrm{P}<0.05)$ between ALP of gills exposed to the treatments compared with the control. AST activity was highest (1946.29 $\mu / \mathrm{L})$ in the gill exposed to $1.25 \mathrm{~g} / \mathrm{L}$ of WSFs of WDCB while the lowest value $(1825.12 \mu / \mathrm{L})$ was recorded in the control $(0.00 \mathrm{~g} / \mathrm{L})$. There was no significant difference $(\mathrm{P}>0.05)$ between the AST of gills exposed to the treatments compared with the control. Gills ALT activity was highest $(4610.94 \mu / \mathrm{L})$ in the highest toxicant concentration $(5.00 \mathrm{~g} / \mathrm{L})$ while the lowest value $(2013.75 \mu / \mathrm{L})$ was recorded in the control tank $(0.00 \mathrm{~g} / \mathrm{L})$, Statistics indicate significant difference $(\mathrm{P}<0.05)$ between ALT of gills exposed to treatment $5.00 \mathrm{~g} / \mathrm{L}$ compared with the control $(0.00 \mathrm{~g} / \mathrm{L})$ as shown in Figure 1.

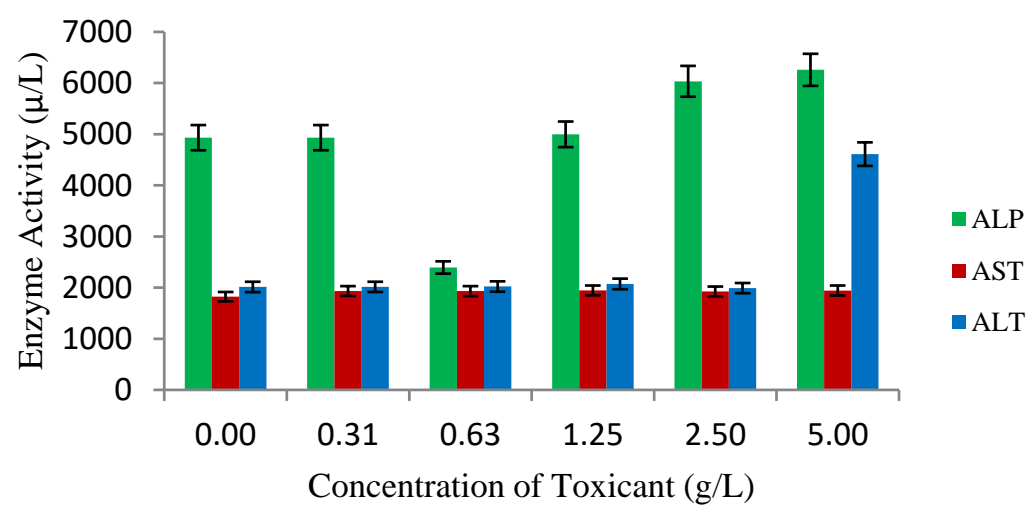

Figure 1 Effects of acute concentrations of WSFs of WDCB on biochemistry of gills of C. gariepinus fingerlings

The biochemistry of the liver of C. gariepinus_exposed to WSFs of WDCB showed that ALP activity was highest (3995.75 $\mu / \mathrm{L})$ in the control tank $(0.00 \mathrm{~g} / \mathrm{L})$ while the lowest value $(2370.50 \mu / \mathrm{L})$ was recorded in $2.50 \mathrm{~g} / \mathrm{L}$ concentration of the toxicant (Figure 2). Statistically, there was significant difference $(\mathrm{P}<0.05)$ between ALP of liver exposed to acute 
concentration compared with the control. Highest AST activity (4610.92 $\mu / \mathrm{L})$ was recorded in the liver exposed to 5.00 $\mathrm{g} / \mathrm{L}$ concentration of WSFs of WDCB while the lowest value $(1833.42 \mu / \mathrm{L})$ was recorded in the control tank $(0.00 \mathrm{~g} / \mathrm{L})$ (Figure 2). Significant difference $(\mathrm{P}<0.05)$ exists between liver of $C$. gariepinus exposed to treatment concentration $(5.00$ $\mathrm{g} / \mathrm{L})$ compared with the control. Similarly, ALT activity was highest ( $2015.52 \mu / \mathrm{L})$ in the liver exposed to $0.63 \mathrm{~g} / \mathrm{L}$ acute concentration of WSFs of WDCB while the lowest value was recorded in the liver exposed to the highest concentration $(5.00 \mathrm{~g} / \mathrm{L})$ of test substance (Figure 2$)$. There was, however, no significant difference $(\mathrm{P}>0.05)$ between the liver exposed to acute concentrations compared to the control.

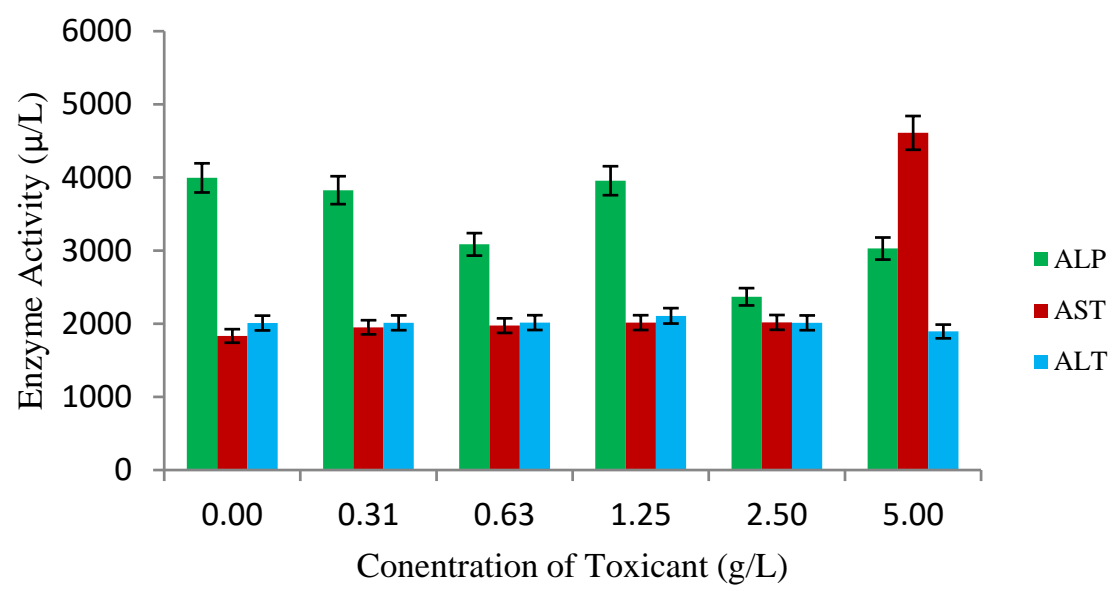

Figure 2 Effects of acute concentrations of WSFs of WDCB on biochemistry of liver of C. gariepinus fingerlings

\subsection{Biochemistry of $C$.gariepinus fingerlings exposed to sub lethal concentrations of water soluble fractions of WSFs of WDCB}

The mean values of ALP, AST and ALT of the gills and liver of $C$. gariepinus fingerlings exposed to sub lethal concentrations of WSFs of WDCB are presented in Figures 3 and 4. The highest ALP activity (8327.35 $\mu / \mathrm{L})$ in the gill of the fingerlings was recorded in the control tank $(0.00 \mathrm{~g} / \mathrm{L})$ while the lowest value $(6451.25 \mu / \mathrm{L})$ was recorded in sub lethal concentration $0.07 \mathrm{~g} / \mathrm{L}$. The highest AST activity $(4034.29 \mu / \mathrm{L})$ in the gills was recorded in sub lethal concentration $0.02 \mathrm{~g} / \mathrm{L}$ of WSFs of WDCB while the lowest value $(3369.81 \mu / \mathrm{L})$ was recorded in treatment concentration $0.04 \mathrm{~g} / \mathrm{L}$. The highest ALT activity $(5037.02 \mu / \mathrm{L})$ in the gills was recorded in sub lethal concentration $0.02 \mathrm{~g} / \mathrm{L}$ of WSFs of WDCB while the lowest ALT value $(4596.40 \mu / \mathrm{L})$ was recorded in sub lethal concentration $0.04 \mathrm{~g} / \mathrm{L}$ of the toxicant. Statistical analysis revealed significant difference $(\mathrm{P}<0.05)$ between ALP and AST of gills exposed to treatment concentrations compared with the control while ALT of gills exposed to the treatment concentrations showed no significant difference $(\mathrm{P}>0.05)$ compared with the control.

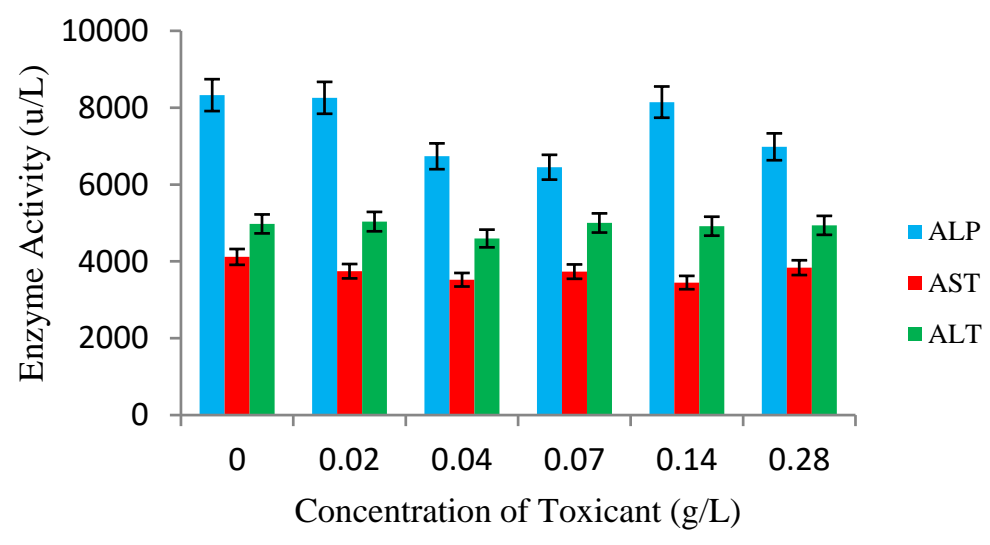

Figure 3 Effects of sub lethal concentrations of WSFs of WDCB on biochemistry of gills of $C$. gariepinus fingerlings 
Effects of sub lethal concentrations of WSFs of WDCB on liver are presented in Figure 4. The highest ALP activity $(8101.25 \mu / \mathrm{L})$ was recorded in the control tank $(0.00 \mathrm{~g} / \mathrm{L})$ while the lowest $(6468.20 \mu / \mathrm{L})$ was recorded in $0.14 \mathrm{~g} / \mathrm{L}$ of the toxicant (Figure 4). The highest liver AST activity $(4117.34 \mu / \mathrm{L})$ was recorded in the control while the lowest $(3447.30 \mu / \mathrm{L})$ was recorded in treatment concentration $0.14 \mathrm{~g} / \mathrm{L}$. The highest ALT activity $(4807.50 \mu / \mathrm{L})$ of the liver was in the highest concentration $(0.28 \mathrm{~g} / \mathrm{L})$ of WSFs of WDCB while the lowest $(4094.34 \mu / \mathrm{L})$ was recorded in $0.0 \mathrm{~g} / \mathrm{L}$ of the treatment concentration. Statistical difference $(\mathrm{P}<0.05)$ exists between ALP, AST and ALT of gills and liver of $\mathrm{C}$. gariepinus fingerlings exposed to sub lethal concentrations of WSFs of WDCB compared to the control.

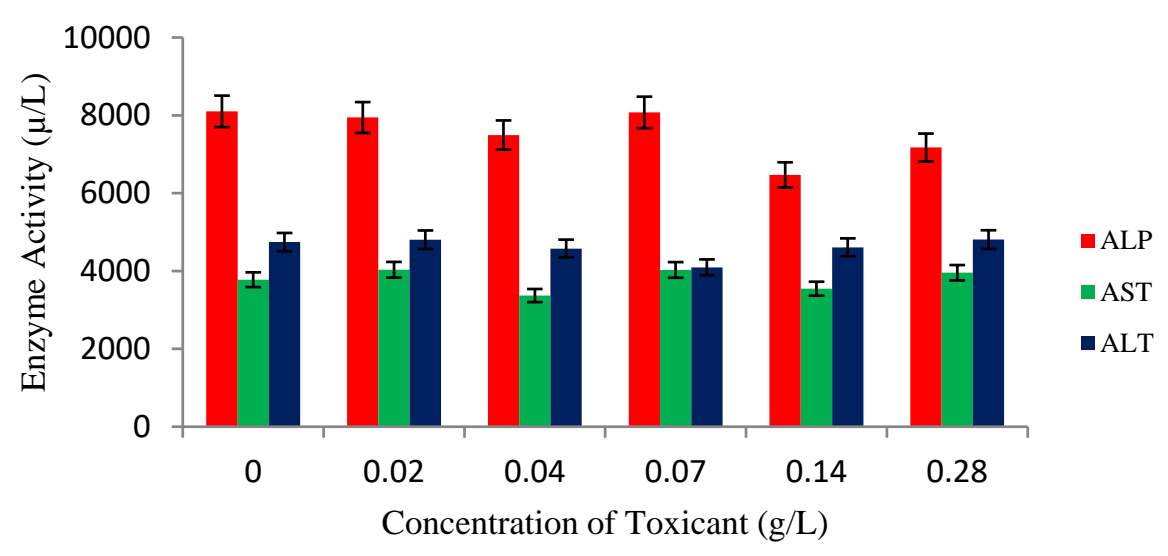

Figure 4 Effects of sub lethal concentrations of WSFs of WDCB on biochemistry of liver of $C$. gariepinus fingerlings

\section{Discussion}

This study showed that WSFs of WDCB which contains heavy metals (zinc and manganese) have detrimental effects on fish following significant alterations in haematology and blood biochemistry of $C$. gariepinus. This confirms the report of Drevnick, Sanheinrich and Al-Gais [10] that heavy metal cause harmful effects on the haematology and organs of fish since they become lodged in organs and tissues [12,13] and are excreted in the blood [14].

The results of water quality parameters in the present study showed significant variations in $\mathrm{DO}$ and Free $\mathrm{CO}_{2}$ compared with the control. TA, Temperature, Nitrite and Ammonia however, showed no significant changes with control. The behavioural abnormalities displayed by the fingerlings in the acute toxicant concentrations in this study may be an indication of DO depletion and increase in free $\mathrm{CO}_{2}$. This result is similar to the findings of [29] who reported decrease in D0 after exposure of C. gariepinus to cassava waste water effluent. In the present study, the lethal dose of $96 \mathrm{hr}$. $\mathrm{LC}_{50}$ value of WSFs of WDCB varied from 0.31 to $5.00 \mathrm{~g} / \mathrm{L}$ and mortality was directly proportional with concentration of WSFs of WDCB concentration. The direct increase in mortality with increase in acute treatment concentrations in this study is in conformity with the report of [30] after measuring pollutant toxicity in fish.

The blood parameters exposed to acute and sub lethal concentrations of WSFs of WDCB indicate increase in PCV, Hb and RBC. Increase in RBC is similar to the findings of [26] who reported increase in RBC following increase in concentration of aluminium (Al) on Tilapia zilli. Dahunsi. Similarly, Salah El-deen \& Roqers [28] and Karrupasamy et al. [13] reported increase in $\mathrm{Hb}, \mathrm{PCV}$ and RBC with increase intoxicant concentration in Grass carp and Channa punctatus respectively. The increase in haematological parameters in this study however disagree with the findings of [29] who reported decrease in haematological parameters such as RBC and PVC in Lates calcarifer exposed to heavy metal. Similarly, the increase in PCV, RBC and $\mathrm{Hb}$ in the present study is in total disagreement with the findings of [30] who reported reduction in RBC, $\mathrm{Hb}$ and PCV after exposure of $C$. punctatus to cadmium and mercury. In this study, sub lethal concentration of WSFs of WDCB on haematology of $C$. gariepinus fingerlings showed decrease in WBC as concentrations of the test material increase.

Enzyme analysis of gills, serum and liver in fish can provide important information about the internal environment of fish [31]. In the present study ALP, AST and ALT exposed to WSFs of waste dry cell battery on C. gariepinus fingerlings increased with increase in the toxicant concentration which corroborated with the findings of [32, 33]. The elevation in values of ALP, AST and ALT corroborates the finding of [31,34] who reported elevation of ALT, AST, and ALP in C. gariepinus and $O$. niloticus respectively as concentration of toxicants increase. 


\section{Conclusion}

Results of the bioassay of WSFs of WDCB on C. gariepinus fingerlings at both acute and sub lethal levels showed visible changes in behaviour, haematology and biochemistry of the gills and liver of C. gariepinus with resultant mortality in the acute concentrations. It could therefore be concluded that WSFs of WDCB is hazardous to C. gariepinus fingerlings. The observed $\mathrm{LC}_{50}$ value may help in determining safer levels of WSFs of WDCB in the aquatic environment. However, it is proposed that indiscriminate dumping of waste dry cell batteries along riparian systems should be regulated to preserve biodiversity of aquatic fauna.

\section{Compliance with ethical standards}

Ethical standards of the Animal House of the Faculty of Pharmaceutical Sciences of the University of Jos, Nigeria, were strictly adhered to.

\section{Acknowledgments}

We wish to acknowledge the immense cooperation of all the technical staff of the Applied Hydrobiology and Fisheries Postgraduate laboratory for their unflinching support and the Department of Zoology, Faculty of Natural Sciences, University of Jos, Nigeria for the provision of space for the conduct of the research work.

\section{Disclosure of conflict of interest}

We declare no conflict of interest.

\section{References}

[1] Mona SZ, Shalaby SI, Nagwa A and Abedelzaher MF. (2013). Effect of aquatic pollution on fish: A Review. Life Science Journal, 10 (1), 637- 632.

[2] Kalay M and Canli M. (2000). Elimination of essential (CU and Zn) and non-essential (Cd and Pb) metals from tissues of freshwater fish, Tilapia Zilli Journal of Zoology, 24, 429-436.

[3] Hasib MD, Mahbub AL, Nandini DEB, Muhammad RA, Shamsul A and Mohidus SK. (2015). Metal Recovery from Waste Dry Cell Batteries. Proceedings of the Waste Safe $4^{\text {th }}$ International Conference on Solid Waste Management in the Developing Countries 15-17February 2015, Khulna, Bangladesh.

[4] Adams SM and Ryon MGA. (1994). A comparison of health assessment approaches for evaluating the effects of contaminant-related stress on fish populations. Journal of Aquatic Ecosystem and Health, 3, 15-25.

[5] Zaki MS, Authman MMN, Hammam AMM and Shalaby SI. (2014). Aquatic environmental pollution in the Egyptian countryside and its effect on fish production (Review). Life Science Journal, 11, 1024-1029.

[6] Rashed MN. (2001). Monitoring of environmental heavy metals in fish from Nasser Lake. Environment International, 27, 27-33.

[7] Authman MMN. (2008). Oreochromis niloticus as a biomonitor of heavy metal pollution with emphasis on potential risk and relation to some biological aspects. Global Veterinarian, 2(3), 104-109.

[8] Lamas S, Fernández JA, Aboal JR and Carballeira A. (2007). Testing the use of juvenile Salmo trutta L. as biomonitors of heavy metal pollution in freshwater. Chemosphere, 67, 221-228.

[9] Al-Yousuf MH, El-Shahawi MS and Al-Ghais SM. (2000). Trace metals in liver, skin and muscle of Lethrinus lentjan fish species in relation to body length and sex. Science Total Environment, 256, 87-94.

[10] Drevnick PE, Sandheinrich MB and Oris JT. (2006). Increased ovarian follicular apoptosis in fathead minnows (Pimephales promelas) exposed to dietary methylmercury. Aquatic Toxicology, 79, 49-54.

[11] Sfakianakis DG, Renieri E, Kentouri M and Tsatsakis AM. (2015). Effect of heavy metals on fish larvae deformities: A review. Environmental Research, 137, 246-255.

[12] Adeyemo OK, Adedeji OB and Offor CC. (2010). Blood lead level as biomarker of environmental lead pollution in feral and cultured African catfish (Clarias gariepinus). Nigerian Veterinary Journal, 31, 139-147. 
[13] Fazio F, Piccione G, Tribulato K, Ferrantelli V, Giangrosso G, Arfuso F and Faggio C. (2014).Bioaccumulation of heavy metals in blood and tissue of striped mullet in two Italian Lakes. Journal of Aquatic Animal Health, 26(4), 278-284.

[14] Karruppasamy R, Subathra S and Puvanes WS. (2005). Haematological responses of exposure to sub lethal concentration of Cadmium in air breathing fish, Channa punctatus (Bloch) Journal of Environmental Biology, 26 (1), 123-128.

[15] Dhanapaktam P and Ramasamy VK. (2001). Toxic effects of copper and zinc mixtures on some haematological and biochemical parameters in common carp. Cyprinus carpio (Linn). Journal of Environmental Biology, 22(2), 105-111.

[16] Thangam Y, Jayaprakash S and Perumayee M. (2014). Effect of copper toxicity on haematological parameters of fresh water fish, Cyprinus carpio (Common carp). IOSR Journal of Environmental Science Technology and Food Technology, 8(9), 50-60.

[17] Dufour DR, Lott JA, Noite FS, Gretch DR. Keff RS and Seeff LB. (2000). Diagnosis and monitoring of hepatic injury. Clinical Biochemistry Standards of Laboratory Practice, 46, 2027-2049.

[18] Firat O, Coqun HY, Yuzereroglu TA, Gok G, Firat O, Kargin F and Kotemen Y. (2011). A comparative study on the effects of a pesticide (cypermethr.in) and two metals (copper, lead) to serum biochemistry of Nile tilapia, Oreochromis niloticus. Fish Physiology and Biochemistry, 37(3), 657-666.

[19] Yang J and Rose NL. (2003). Distribution of Hg in the lake sediments across the UK, Science \& Total Environment, 304, 391-404.

[20] McDonald MD and Grosell M. (2006). Maintaining osmotic balance with an aglomerular kidney. Comparative Biochemistry \& Physiology, 143, 447-458.

[21] Organization for Economic Cooperation and Development. (OECD) (2003). Guideline for the Testing of Chemicals: Fish, Acute Toxicity test, 203, 6-10.

[22] American Public Health Association (APHA). (1985). Standard methods for examination of water and waste water, $16^{\text {th }}$ Edition, Washington D.C. USA. America Public Health, 1268.

[23] Blaxhall PC and Daisley KW. (1973). Routine haematological methods for use with fish blood. Journal of Fish Biology, 5, 771-772.

[24] Nelson DA and Moris MW. (1989). Basic methodology, haematology and coagulation, part IV. In: DA Nelson and JB Henry (Eds) Clinical diagnosis and management by laboratory methods. $17^{\text {th }}$ edition. Philadelphia (PA). WB Saunders, 578-625.

[25] Dacie JV and Lewis SM. (1991). Practical haematology. $7^{\text {th }}$ edition. Edinburgh: Churchill Livingstone.

[26] Deri MPS and Fingerman M. (1993). Effect of exposure on lactate dehydrogenase activities in the hepatopancreas and abdominal muscle of the fiddler crab, Ula pugilato, Comparative Pharmacology and Toxicology, 106(3), 739742 .

[27] Reitman S and Frankel S. (1957). A colorimetric method for the determination of serum of glutamic oxaloacetic and glutamic pyruvic transaminase. American Journal of Clinical Pathology, 28, 56-63.

[28] Saleh-El-Deen MA and Rogers WA (2002). Acute toxicity and some haematological changes in grass carp exposed to Diquate. Journal of aquatic Animal Health, 4 (4): 277-280.

[29] Adewoye SO, Fawole 00, Owolabi OD and Omotosho JS. (2005). Toxicity of cassava waste water effluent to African catfish, Clarias gariepinus. Ethiopia Journal of Science, 28(7), 189-194.

[30] Senthamilselvan D, Chezhian ES and Ezhilmathy R. (2012). Toxic effects of heavy metals (cadmium plus mercury) on haematological parameters and DNA damage in Lates calcarifer. Journal of Toxicology and Environmental Health Sciences, 4(9), 156- 161.

[31] Akinrotimi OA, Edun OM and Ukwe, OIK. (2018). Effects of anaesthetics on metabolic enzyme activities in African Catfish, Clarias gariepinus (Burchell, 1822). Journal of Fisheries Science, 12(1), 22-28.

[32] Ptashynsky MD, Pedlar RM, Evans RE, Boron CL and Klavercamp JF. (2002). Toxicology of dietary nickel in lake white fish (Caregonus clupeaformis). Aquatic Toxicology, 58, 229-24. 
[33] Wade JW, Omoregie E and Ezenwaka F. (2002). Toxicity of Cassava (Manihot esculenta) effluent on the Nile catfish (Clarias gariepinus) under laboratory condition. Journal of Aquatic Sciences, 17, (2):69-94.

[34] Alaa GMO, Khaled YA, Abdelbaset MA, Usama M M, Wermer K and Mohsen AM. (2018). Blood biomarkers in Nile Tilapia (Oreochromis niloticus) and African Catfish (Clarias gariepinus) to evaluate water quality of the River Nile. Journal of Fisheries Science, 12(1), 1-15.

\section{How to cite this article}

Audu BS, Damshit M, Wakawa IA, Ajima MNO, Sulaiman Y and Wade JW. (2020). Toxicity effects of waste dry cell battery on the haematology and biochemistry of blood, gills and liver of Clarias gariepinus fingerlings. World Journal of Advanced Research and Reviews, 6(2), 72-82. 